\title{
Unexpected case of non-syndromic neighbouring basal cell carcinomas
}

\author{
Kerasia-Maria Plachouri, ${ }^{1}$ Francesk Mulita (D) ,' Sophia Georgiou, ${ }^{1}$ \\ Theofanis Spiliopoulos ${ }^{3}$
}

'University of Patras—Patras Campus Rion, Patras, Greece ${ }^{2}$ Department of General Surgery, University General Hospital of Patras Holy Mary the Help, Patras, Greece

${ }^{3}$ Dermatology Department, University General Hospital of Patras, Patras, Greece

\section{Correspondence to}

Francesk Mulita;

oknarfmulita@hotmail.com

Accepted 15 November 2020

\section{DESCRIPTION}

A 66-year-old Caucasian woman (Fitzpatrick skin type III) presented in our department for the evaluation of a lesion in the lumbosacral area, that had first appeared approximately 3 years prior to the referral and was gradually progressing in size. The lesion was a pruritic erythematous and slightly hyperkeratotic papule that, according to the patient, was constantly irritated through contact with clothes, and was occasionally bleeding. During the whole-skin physical examination two other suspicious lesions were documented in a linear distribution in the immediate vicinity of the abovementioned papule (figure 1). The first presented as an erythematous macula and the second presented as a slightly elevated plaque with an irregular multifocal brown pigmentation in the periphery. The histological examination of the lesions revealed three basal cell carcinomas (BCCs). The tumours were surgically removed via an elliptical excision and the patient was advised to present for regular skin examination follow-ups, given the recurrence rates of BCCs. ${ }^{12}$ The patient was otherwise healthy, without signs of Gorlin-Goltz syndrome or other hereditary disorders, history of malignancy, exposure to cancerogenic substances such as arsenic, topical radiation, solarium treatments or excessive sunbathing. She further denied cases of skin cancer in the family history.

BCC is the most common skin neoplasm, with multiple causes such as ultraviolet (UV) radiation exposure, genetic predisposition with Fitzpatrick skin types I and II, or hereditary conditions, such as Xeroderma pigmentosum and Gorlin-Goltz syndrome. ${ }^{1}$ For the cases where numerous BCCs occur without the evident influence of an extrinsic risk factor, the term multiple non-syndromic BCCs is used. ${ }^{2}$ The reporting of such patients in

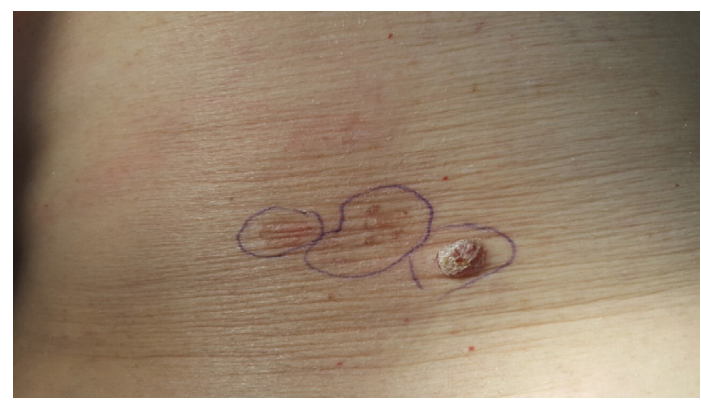

Figure 1 Macroscopic image of the three basal cell carcinomas located on the lumbosacral region of the patient.

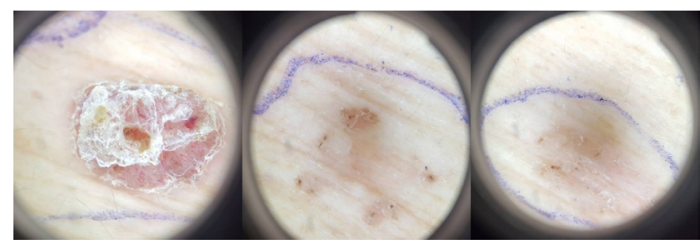

Figure 2 Dermatoscopic images of the three basal cell carcinomas located on the lumbosacral region of the patient.

the literature is very limited, and the BCCs in the described cases tend to have similar morphological characteristics. $^{2}$

Dysregulated Hedgehog signalling is a hallmark of BCC pathogenesis. ${ }^{3}$ The cellular origin of these tumours is believed to arise from the basal cells of the interfollicular epidermis and infundibulum of hair follicles. ${ }^{3}$ Although the exact pathogenesis of non-syndromic BCCs is not fully elucidated, an association with the biological events that lead to cutaneous field cancerisation can be speculated. The pathogenetic mechanism of field cancer is based on the following model: acquired genetic alterations in skin stem cells (mostly UV-induced) give origin to proliferating clones that expand in the epidermis and form patches of mutated cells. ${ }^{4}$ These clones and subclones acquire additional mutations that can result in carcinomatous transformation over time. ${ }^{4}$

The synchronous appearance of multiple neighbouring BCCs with distinct clinical and dermatoscopic characteristics on areas that are not sun-exposed and in otherwise healthy patients, without history of malignancy or other relevant comorbidities, such as immunosuppression or other pathogenic background, and without relevant family history, is rather uncommon. ${ }^{2}$ The peculiar coincidence in our case is the immediate proximity of the three BCCs, their unusual distribution in a

\section{Learning points}

- The simultaneous appearance of multiple neighbouring basal cell carcinomas in areas of healthy individuals that are not sun-exposed, without the influence of external risk factors, is rare but possible.

- Physicians should not hesitate to perform biopsies in such uncertain cases, because clinical suspicion is a more significant parameter than statistical probabilities. 
linear pattern and the fact that they displayed different macroscopic and dermatoscopic features (figure 2).

The objective of this article is to raise awareness over the existence of non-syndromic BCCs and to point out that physicians should not hesitate to perform diagnostic biopsies in uncertain cases. Clinical suspicion is a factor that should not be underestimated, even in cases of low probability of cutaneous neoplasias.

Contributors K-MP and TS had the idea of the study. K-MP and FM prepared the manuscript. SG and TS critically revised the manuscript. All authors accepted the final version of the manuscript.

Funding The authors have not declared a specific grant for this research from any funding agency in the public, commercial or not-for-profit sectors.

Competing interests None declared.
Patient consent for publication Obtained.

Provenance and peer review Not commissioned; externally peer reviewed.

\section{ORCID iD}

Francesk Mulita http://orcid.org/0000-0001-7198-2628

\section{REFERENCES}

1 Kim DH, Ko HS, Jun YJ. Nonsyndromic multiple basal cell carcinomas. Arch Craniofac Surg 2017;18:191-6.

2 Orgaz-Molina J, Fernández-Pugnaire MA. Multiple superficial and pigmented basal cell carcinomas: do these represent a type of multiple non-syndromic basal cell carcinoma? Int J Dermatol 2014:53:e284-6.

3 Tan ST, Ghaznawie M, Heenan PJ, et al. Basal cell carcinoma arises from interfollicular layer of epidermis. J Oncol 2018:2018:3098940.

4 Torezan LAR, Festa-Neto C. Cutaneous field cancerization: clinical, histopathological and therapeutic aspects. An Bras Dermatol 2013:88:775-86.

Copyright 2020 BMJ Publishing Group. All rights reserved. For permission to reuse any of this content visit

https://www.bmj.com/company/products-services/rights-and-licensing/permissions/

BMJ Case Report Fellows may re-use this article for personal use and teaching without any further permission.

Become a Fellow of BMJ Case Reports today and you can:

- Submit as many cases as you like

- Enjoy fast sympathetic peer review and rapid publication of accepted articles

Access all the published articles

Re-use any of the published material for personal use and teaching without further permission

Customer Service

If you have any further queries about your subscription, please contact our customer services team on +44 (0) 2071111105 or via email at support@bmj.com.

Visit casereports.bmj.com for more articles like this and to become a Fellow 